\title{
Evolution of arid landscape in India and likely impact of future climate change
}

${ }^{1}$ Kolkata; Formerly of Central Arid Zone Research Institute, Jodhpur, India

${ }^{2}$ Wadia Institute of Himalayan Geology, Dehradun, India

(Received : 5/12/2018; Revised accepted : 24/7/2019)

https://doi.org/10.18814/epiiugs/2020/020033

Thar Desert and Ladakh are two prominent arid areas in the Indian Subcontinent, representing the hot and the cold arid regions, respectively. Landforms in Thar Desert have developed over a relatively stable platform, and bear strong impressions of several cycles of late Quaternary climate change between warm wet and dry cool phases, which dictated the spatiotemporal distribution of the fluvial and aeolian processes and the typical disposition of the landforms. By contrast, Ladakh, located in the Trans-Himalaya, is mountainous and dominated by glacial, periglacial and fluvial processes, with fewer signatures of lacustrine and aeolian processes. Since 44 ka, the area witnessed two major and one minor phases of aridity. Evidence for neotectonic, though expected very much in this suture zone between the Indian and the Eurasian plates, is not very common, and need proper investigation. Presently anthropogenic activities tend to have over-bearing influences on the process acceleration and land degradation in both Thar Desert and Ladakh. Since warming-related changes in climate have also started to impact the areas, sustainable land uses, backed up by land conservation measures are called for.

\section{Introduction}

Arid lands occupy 14 per cent of India's total land area, and include both hot and cold arid regions. While the major part of the hot arid region occurs in the state of Rajasthan that includes the sandy Thar Desert, the cold arid region occurs exclusively to the north of the Zanskar Range in the Trans-Himalaya, where it includes a vast swath of mountainous land from Ladakh in the southeast to GilgitBaltistan in the northwest (Fig. 1). Aridity here is quantified as a moisture availability index (Im, as defined by India Meteorological Department) of -66.66 to -91.00 . Apart from the vast arid land in western India, small patches of hot arid areas also occur in the southern part of the country, especially in parts of Karnataka, Andhra Pradesh and Maharashtra. The landforms in the hot arid region have largely developed on a dominantly stable Pre-Cambrian platform, except in Kachchh and Saurashtra where they bear strong impressions of recent tectonic activities along the continental margin. By contrast, the landforms in the cold arid region are mountainous, and have developed at the junction of the quasi-mobile Indian and the Eurasian plates. This factor, as well as the vast difference in thermal regime of the two regions, determines the types of subaerial denudation processes in the two regions, even though both the areas receive $\sim 300 \mathrm{~mm}$ or less mean annual precipitation (Krishnan and Thanvi, 1977; Hobley et al., 2012; Fig. 2). Thus, while the hot arid region is largely dominated by wind erosion and/or sheetwash and periodic flooding by ephemeral streams, the cold arid region is subjected to glacial, glacio-fluvial and periglacial processes and mass wasting. Stream processes are more efficient in Ladakh due to the presence of many-glacial-fed large streams like the Indus and its tributaries. We describe below the landscape development in the two regions with examples from Thar Desert and Ladakh.

\section{Thar Desert}

The Thar, or the Great Indian Sand Desert, stretches between the foothills of the denuded Pre-Cambrian Aravalli hill ranges in Rajasthan state of India and the Indus River in Pakistan (Fig. 3). Although it lies at the eastern end of a vast arid land along the Tropic of Cancer that includes the hyper-arid Sahara, the Rub-al Khali and the Lut, Thar Desert has a much lower aridity than those extreme deserts due to its location at the transition of two major rain-bearing climate systems, the Indian summer monsoon (ISM) that brings about 100$500 \mathrm{~mm}$ rainfall, and a Mediterranean westerly system that sometimes brings showers of $<100 \mathrm{~mm}$ during the winter and the spring. The land to its south, the Kachchh Peninsula and the Saurashtra Uplands in Gujarat, and that to its north, the thick sandy alluvium in the southern parts of Punjab and Haryana, also belong to the arid lands, but have lower aridity.

\section{Present-day landforms}

Most present-day landforms in Thar Desert bear strong imprints of fluctuating climate during the late Quaternary period, which dictated the relative dominance of fluvial and aeolian processes over time. Some landforms also bear the evidence of neotectonic movements, 


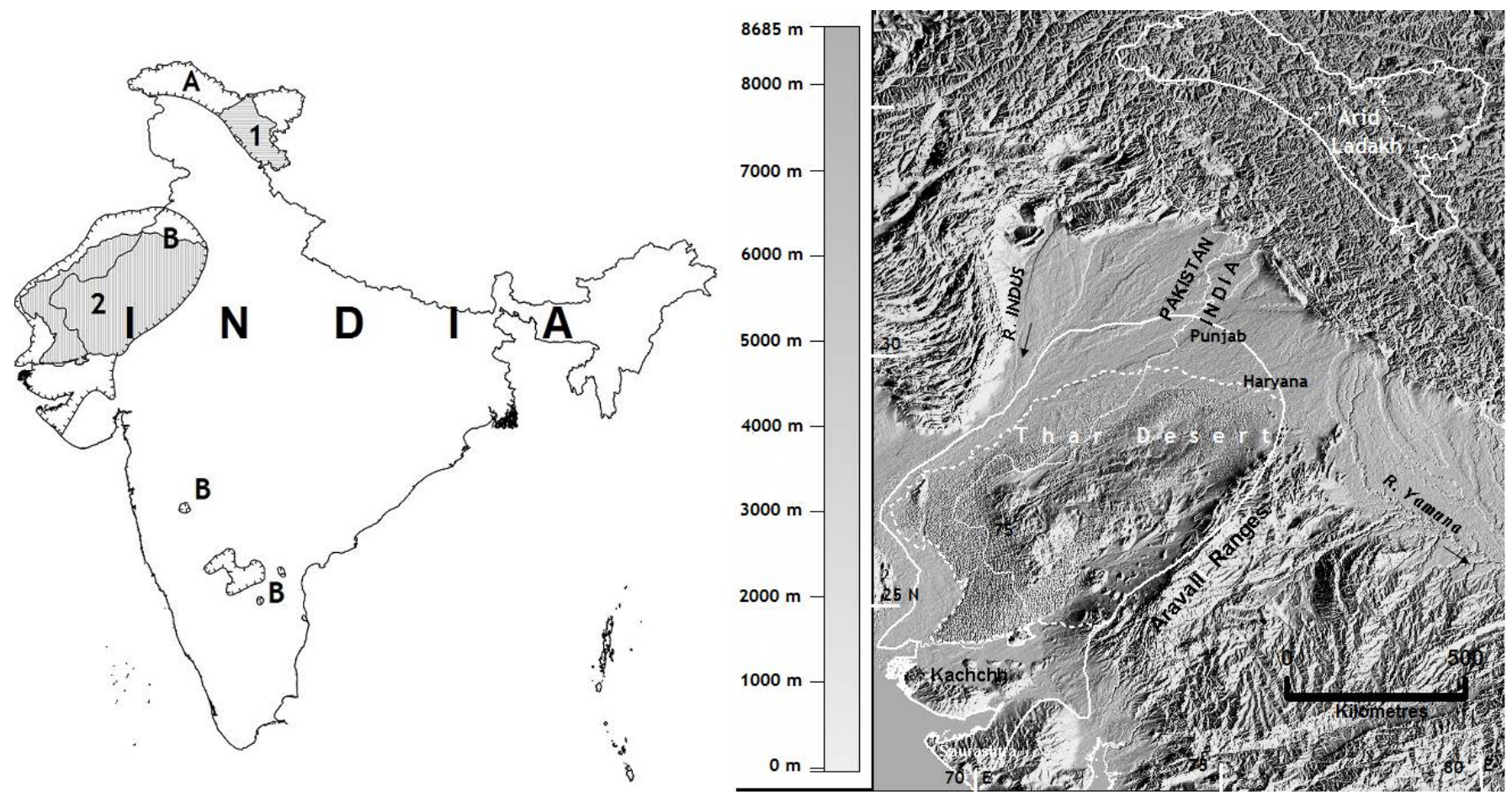

Figure 1. Location of hot and cold arid regions. A: Cold arid region; B: Hot arid regions. 1: Ladakh Desert, India; 2: Thar Desert, India and Pakistan. Image on the right shows the DEM generated from SRTM30-GTOPO data at $1 \mathrm{~km}$ resolution, with the boundaries superimposed.
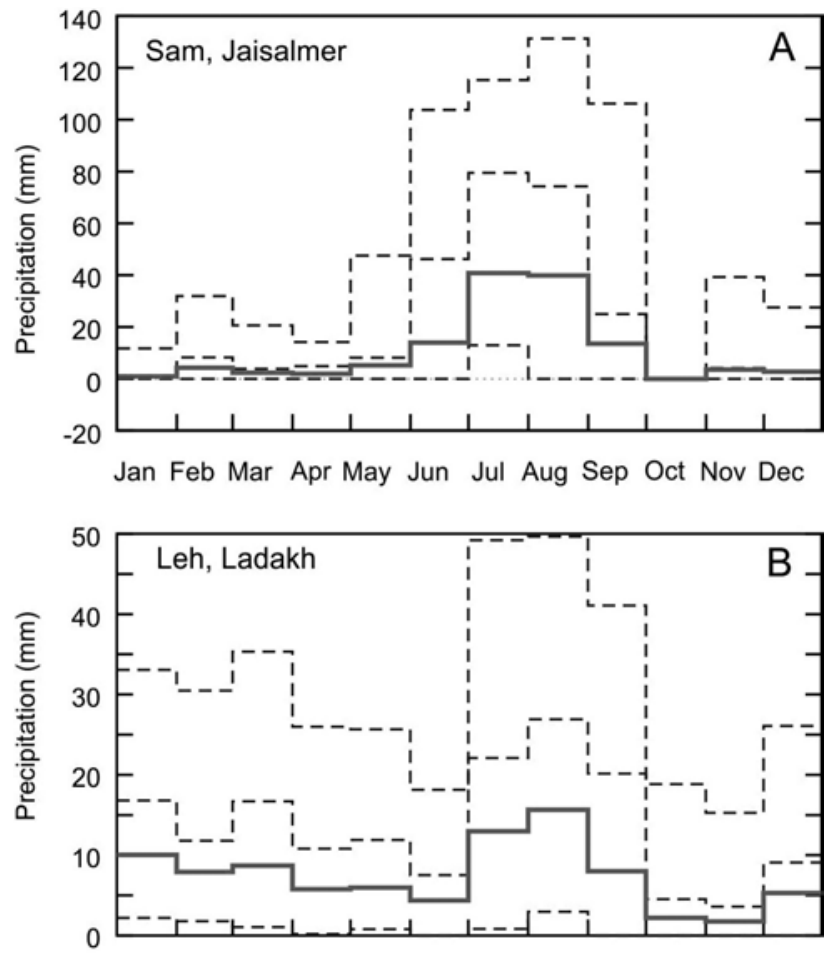

Jan Feb Mar Apr May Jun Jul Aug Sep Oct Nov Dec

- 17\%,83\%,97.5\% percentiles

mean 1981-2017

Figure 2. Monthly precipitation pattern at (A) Sam, west of Jaisalmer, Thar Desert; and (B) Leh, Ladakh. The precipitation data is extracted from KNMI climate explorer for 36 years from 1981 to 2017. The dashed lines indicate 17, 83 and 97.5 percentiles and the bold grey line is for mean. (https://climexp.knmi.nl/start.cgi) while strong signatures of human influences do also abound. Spatially, there exists presently a gradient of fluvial process efficacy from east to west, commensurate with the decreasing ISM rainfall in that direction ( $\sim 500 \mathrm{~mm}$ in the east to $100 \mathrm{~mm}$ in the west), while the aeolian processes are stronger in the west and southwest, but become subdued towards east and north as the wind strength declines in that direction. This overall pattern is also dictated by strong seasonality of the weather. As the climate fluctuated between warmer wet and cooler dry phases at century to millennial scales, the process zonation and process efficacies also shifted, leaving their imprints in the sedimentary beds (Kar, 2014). The climate being arid, weathering processes are very slow in the region, but these prepare the materials for transportation and subaerial denudation. Based on the dominant processes the landforms could be broadly classified into fluvial, aeolian and lacustrine. The major fluvial landform sequence is: hills and uplands - rocky/gravelly pediments (and pavements) - colluvial plains - older alluvial plains - younger alluvial plains - river beds, which supply the aeolian processes materials for constructing over them the sand sheets, sandy hummocks and sand dunes of different types. Such complementary roles of the two processes continued throughout the Quaternary period, making most old land features polygenetic in nature. Because of insufficient drainage, deflation and land segmentation across stream valleys due to aeolian activities, as well as neotectonic activities, a number of salt playas (locally called the Ranns) of different shapes and sizes have also been formed within the desert (Kar, 1995). Based on the assemblages of landforms and their dominant characteristics, following seventeen major geomorphic provinces have been identified (Kar, 2014): (1) Aravalli Hills; (2) Alluvial plains of the north; (3) Star dune field; (4) Transitional parabolic dune field; (5) Luni alluvial plain; (6) Siwana Hills; (7) Transverse dune field of NW; (8) Parabolic dune field of NW; (9) Hamada landscape; (10) Gravel pavements with sand streaks; (11) 
Parabolic dune field of south; (12) Nagarparkar Upland; (13) Saline alluvial plain of NW; (14) Transitional parabolic dune field of NW; (15) Rohri Upland; (16) Network dune field of west; and (17) Linear dune field with megabarchan fields in west (Fig. 3).

\section{Plinth of the Quaternary landforms}

A vast pediplaned surface, composed largely of Pre-Cambrian metasediments and igneous rocks in the east and on gradually thickening sedimentary beds of Mesozoic and Tertiary periods in the west, provided the basement for Quaternary landform development (Sinharoy et al., 1998). The oldest formation in the region is found in the Aravalli Hills tract as the Banded Gneissic Complex (BGC; Heron, 1953), which is dated to 3.5-2.5 Ga (Meert et al., 2010). It hosted the Delhi Supergroup of rocks ( $2.00 \mathrm{Ga})$ that formed the Aravalli Mountain chain, or the Delhi Fold Belt ( $\sim \mathrm{Ga}$ ), as part of the Great Indian Proterozoic Fold Belt along the western edge of the ancient Rodinia Supercontinent (Ashwal et al., 2013). A series of volcanic events between $1700 \mathrm{Ma}$ and $750 \mathrm{Ma}$ along the south-western margin of the mountain produced the Sendra Granite, Erinpura Granite, Malani Igneous Suite, Mt. Abu Granitoids, etc., which extended the continental margin of the period westward, and hosted the younger meta-sediments, including the Marwar Supergroup of sedimentary rocks (Meert et al., 2010, Ashwal et al., 2013, Davis et al., 2014). Northward wandering of the continent and sedimentation in four major segmented basins (i.e., the Nagaur Basin, the Jaisalmer Basin, the Barmer Basin and the Sanchor Basin) since then gradually built up the terrain through the Mesozoic and Tertiary periods to the early Quaternary stage and brought the desert to its present position (Sinharoy et al., 1998, Davis et al., 2014, Wadhawan, 2018). The oldest surviving Quaternary deposits over large parts of the desert are a mixture of sand and gravel, which hint at a dominantly fluvial landscape during the early Quaternary period. Partly-calcreted aeolian sand sheet deposits have also been found in patches to lie directly over the basement, especially in the central and western parts (Dhir et al., 2010), which suggest that the aeolian features were also an integral part of the landscape.

\section{Fluvial landscape evolution}

The ephemeral Luni River and its tributaries from the Aravallis constitute the major river system of the desert. A number of other

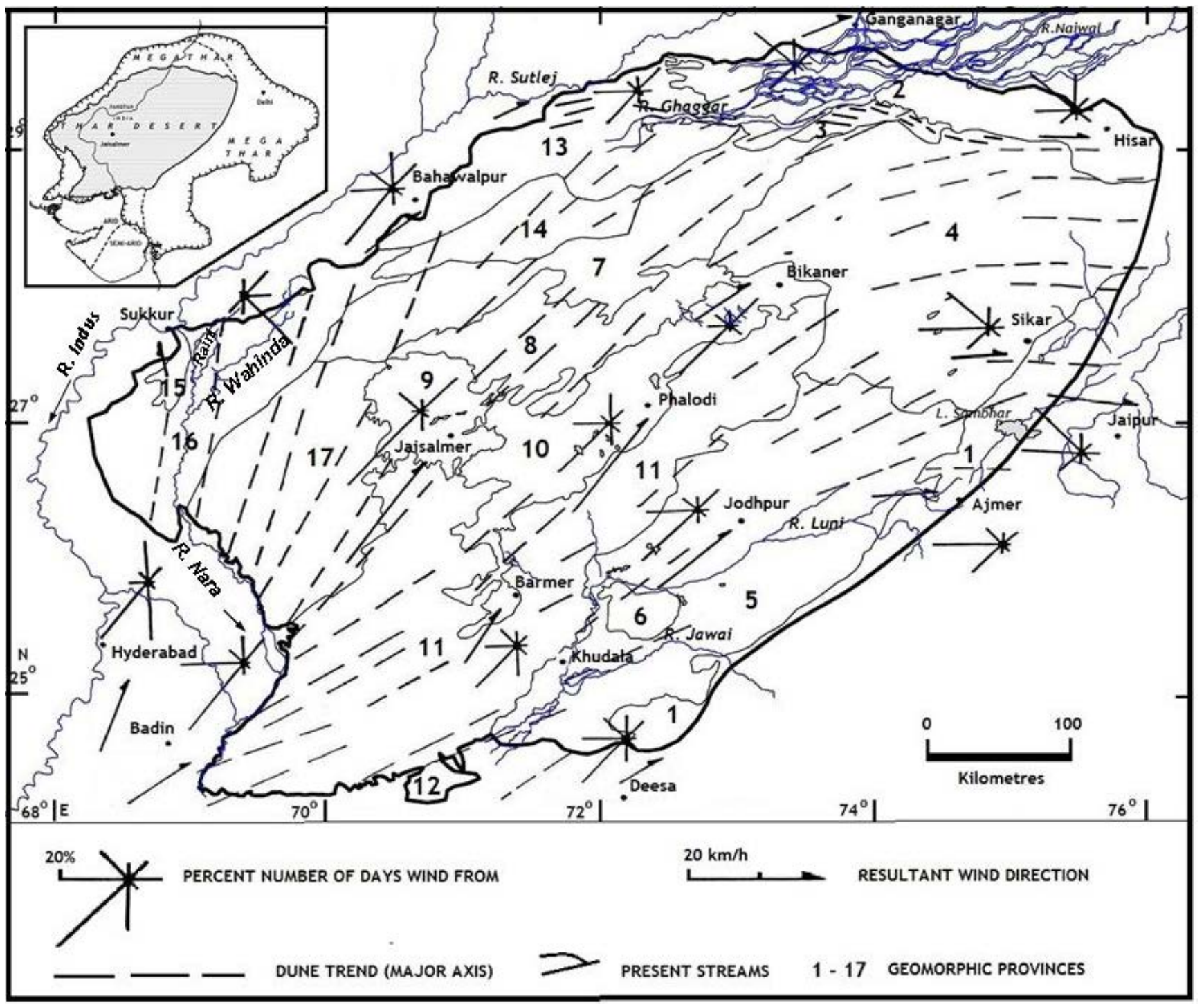

Figure 3. Geomorphic provinces, wind pattern and dune trend in Thar Desert. Details of geomorphic provinces 1-17 are given in text. 
short ephemeral streams from isolated hills in the desert flow for shorter distances during the rains. The wide misfit valley of a Himalayan stream, the Ghaggar River, lies along the northern fringe of the desert. Its discontinuous segments have been traced along the desert's western fringe as the Raini, the Wahinda and the Nara (Fig. 3). C.F. Oldham (Anon., 1874), from his interpretation of topographical sheets and field observations first suggested anonymously that this misfit wide valley of the presently seasonal Ghaggar River, and some other abandoned valleys known as the Naiwals, were actually the former channels of a major Himalayan river, the Sutlej, which used to flow into the Arabian Sea independent of the Indus, and that the Ghaggar-Nara segment of the river was possibly the Saraswati River of the ancient Indian literature. This was the first major suggestion of a Himalayan stream draining the northern and westernmost parts of the desert. Satellite remote sensing helped to trace a maze of buried courses of that system through the plains of Punjab and Haryana, and then through the desert itself (Ghose et al., 1979; Kar and Ghose, 1984). Mica-rich sandy alluvium, vegetation banding, spatially arranged evaporite sequences, e.g., calcrete, gypsum and sodium salts, and shallow potable aquifer fieldvalidated some of those satellite-derived palaeochannels through the dune-infested terrain.

Based on chrono-stratigraphic evidence from the Ghaggar palaeovalley in India (Singh et al., 2016) it is now understood that 155 kilo annum before present (ka), a thick aeolian sand sheet, intercalated with silty sand, covered the surface of the valley. Abundance of silt in some layers suggested either a sluggish flow or a dominant aeolian process reworking some of the older fluvial deposits. From $\sim 75 \mathrm{ka}$ the valley received the Satluj alluvium, the major influxes likely taking place around $70 \mathrm{ka}$ and between $60 \mathrm{ka}$ and $25 \mathrm{ka}$. Since the Last Glacial Maximum (LGM, 25-18 ka) the valley received only some intermittent flows from smaller seasonal streams with frequent aeolian intercalations. At the tail-end of the Ghaggar valley in Pakistan detrital zircon from the Yamuna River basin was traced in the $>49$ ka fluvial sand layer, and was interpreted as the Yamuna's westward flow (Clift et al., 2012). In the core of the desert, chrono-stratigraphic sequences in the lower part of the Luni River at Khudala revealed major pluvial phases during $\sim 80-90 \mathrm{ka}, \sim 55 \mathrm{ka}, \sim 30 \mathrm{ka}$ and 7-6 ka, which matched with the signatures of stronger monsoon elsewhere (Kar et al., 2001; Jain et al., 2005). All such pluvial phases accelerated the fluvial processes and stabilized the sand dunes. Climate simulation results suggest that the Eemian Interglacial $(\sim 127 \mathrm{ka})$ was a period of still higher rainfall in South Asia, but fluvial deposits of that period are yet to be properly dated and evaluated. An interesting but littleexplored landform in the rocky terrain of Jaisalmer and in the northern part of the Luni alluvial plain is a series of palaeo-karstic features, including sinkholes, shallow dolines and uvalas that are partly buried under recent deposits. The features could have been formed during some of the past major pluvial phases. The pluvial phases were followed by major dry phases. The atmospheric conditions since the Eemian period and their likely influence on landscape processes are now being understood through climate simulation modelling and proxy studies (e.g., Shin et al., 2003; Groll et al., 2005; Caley et al., 2014; Dutt et al., 2015).

\section{Aeolian processes and bedform evolution}

The most dominant landforms in Thar Desert are the sand dunes which can be broadly classified into the 'old' and the 'new' ones. The old dunes are typically 15-30 m high, stabilized with copious carbonate nodules and shrub vegetation, and belong mostly to the linear, parabolic, transverse, star, and network types. The axial trend of old linear and parabolic dunes broadly change from NNE in the westernmost part to NE in the central part to ENE in the easternmost part, as the summer wind speed declines gradually towards east and north. In the northern part of the desert, where critical sand-raising wind typically blows from WNW during late-winter and spring, and from SW in summer, the dune orientation tends to replicate both the wind vectors, and thus assumes either a network pattern, or a star shape in fern-leaf pattern (Fig. 3). The new dunes include the 1-8 m high barchans and the 20-40 m high megabarchanoids, which form naturally in the high wind energy regime in the west, as well as 1-3 m high nebkhas and sand streaks that form in the sandy plains anywhere in the desert, but normally abound around the settlements and the deep-ploughed sandy croplands. Linear to sinuous sand ridges ( 2-5 m) form along the banks of many ephemeral streams as sourcebordering dunes, where the channels supply much of the sediments through funnelling effect (Kar, 1993a). Such dunes in the northern alluvial plain now help to trace the palaeo-valleys of the Ghaggar and the Naiwals in a canal-dominated terrain. Under increased dryness and with adequate sand supply from upwind sources, the stream valleys gradually attract more aeolian sand as crescentic to transverse bedforms which tend to bury the valleys altogether. The transverse bedforms are efficient sand captors, while the source-bordering linear dunes act more as sand-passing bedforms (Kar, 1993b). Such complex fluvial-aeolian interactions explain the typical dune landscape along some of the major buried stream valleys to the west of Bikaner and Jaisalmer. The Aravallis and the other major hill fronts are draped with gullied obstacle dunes in the form of whalebacks and echo dunes, where alternate layers of aeolian sand and fluvial gravels record the cycles of the two processes at annual to millennial scales.

Normally aeolian activities are expected to increase with aridity, the peaks coinciding with extreme aridity (i.e., often during a glacial climate). OSL dating of sediments in Thar Desert, however, show that aeolian sand accumulation was higher during the transition from drier to wetter phases, i.e., from glacial to interglacial stages, especially during 115-100 ka, 85-75 ka, 65-60ka, 55-50 ka, 30-25 ka and 14$7 \mathrm{ka}$, when the SW wind gradually strengthened with the northward shift of the ITCZ, but a vigorous monsoon regime was yet to be reestablished (Kar et al., 2001, 2004; Singhvi and Kar, 2004). This synchronism between SW monsoon wind and aeolian sand accumulation is strikingly similar to the modern era summer wind dictating significant aeolian sand mobilization. It strengthens our previous process-based argument that the monsoon strength determined the efficiency of aeolian processes and dune-building activities in Thar Desert during the Quaternary period (Kar, 1993a).

Most sand dunes within the desert and beyond its eastern boundary recorded a strong phase of aeolian sand deposition during 14-10 ka, although the process started around $16 \mathrm{ka}$. The desert extended far to the east of its present limit and into the present-day semi-arid eastern Rajasthan (Goudie et al., 1973). By 10 ka increased monsoon rains stabilized the sandy landscape to the east of the desert, but within the desert the large-scale aeolian activities continued till $\sim 7$ ka (i.e., the Climatic Optimum). Available OSL dates suggest that aeolian activities within the desert picked up again from $\sim 5.0$ ka to 3.5 ka when monsoon rains had declined. Incidentally, it was during this phase that the misfit stream valleys along the desert's northern and western fringes hosted a large number of Harappan settlements ( 4.5-3.9 ka). This was 
followed by another phase of high aeolian activity during 2.0-0.6 ka, but the sandy landscape to the north, east and south of Thar Desert did not record much activity. Remnants of the pre-10 ka aeolian sand bodies beyond the present desert boundary now help to fix the approximate boundary of a Mega-Thar (Fig. 3). The latest phase of sand mobility in the desert started around $0.3 \mathrm{ka}$, when the rates of dune mobility and sand accretion began to surpass the geological rates due to increasing human pressure, especially in the postindependence era when large-scale shifts in land use took place from traditional animal-based mixed-farming to modern irrigated farming with tractor use (Kar et al., 1998, Kar, 2014).

Although the weak W to NW wind of LGM did not allow much aeolian activity within the desert, several fossil dunes beyond the desert's southern margin in Gujarat recorded high aeolian activity, especially in the Mahi and the Sabarmati river catchments, possibly due to a lower sea level during LGM, which exposed a wide stretch of coastal sand to a longer fetch of strong wind over a sparsely vegetated surface (Juyal et al., 2003). In the northernmost part, continuity of sand accretion and dune-building processes during weak monsoon phases cannot be ruled out, because the NW wind is stronger here than in the south. Presently the area experiences sand mobilization during both spring (NW wind) and summer (SW wind), which explain the multi-directional arms of the old star and network dunes.

\section{Fluvial-aeolian interactions in Rann (playa) formation}

Presently significant aeolian erosion of the rocky/gravelly tract can be noticed in the very dry hamada landscape of JaisalmerRamgarh, where constant etching and grooving of the gentle NWdipping soft limestone beds by strong sand-surcharged SW wind leads to the formation of small depressions with micro-scarps. Over the millennia, the small depressions gradually coalesce to form few large en-echelon depressions and then evolve into saline Ranns under a strong evaporative regime, as has been the case with Mithar Rann, Khara Rann, Kanodwala Rann, etc., near Jaisalmer (Kar, 1993b). A series of yardangs have also formed in the vicinity. Elsewhere in the desert, deflation hollows in the wake of isolated hills, flanked by linear dunes, capture and confine the seasonal run-off from surrounding areas to form ephemeral lakes, which subsequently evolve into saline Ranns (e.g., at Degana, Didwana, Jaidu; Kar, 1990). A few other Ranns appear to have evolved as tectonic basins (e.g., at Sambhar, Kuchor). All the major Ranns experienced a hypersaline environment during the LGM. Subsequently, most Ranns in the eastern part experienced freshwater conditions during stronger monsoons, but those in the extreme west either missed the event or experienced it for a brief period because rainfall did not fluctuate there appreciably after the LGM (Singh et al., 1974; Roy and Singhvi, 2016).

\section{Neotectonic influences}

Apart from the climatic fluctuations, tectonic activities during the Quaternary also played some role in the evolution of desert landscape, especially in the Luni alluvial plain where satellite images revealed a number of lineaments. Striking relationship was noticed between many of the NNE-SSW lineaments and drainage anomalies like sudden widening of channel beds, stream incision and angular bends, as well as small terraces. At least two terraces were identified along many streams, including the Luni to the south of Sindari (Kar,
1988). Signatures of a tectonic event at $\sim 10$ ka were found in the form of oblong mud balls within a fluvio-lacustrine bed of sand-silt at Khudala near the junction of the Luni with the Jawai. It suggested that the semi-viscous lacustrine deposit of the period was subjected to vigorous shaking, followed by northward tilting of the beds. Courses of both the Luni and the Jawai were affected (Kar, 2014).

\section{Present-day human impact}

The fragile landscape of Thar Desert is now under a high risk of sediment mobility, soil erosion and land quality degradation, due to high demand for food, fodder, water and other resources from the land. Destruction of natural plant cover on old dunes, flattening of small dunes and deep ploughing of sandy terrain to expand croplands has increased wind erosion and new dune formation. Misuse of canal water in the palaeochannel-dominated northern part has encouraged waterlogging and salinization. Gully erosion is increasing on many obstacle dunes in the Aravalli foothills as the land is opened up for irrigated cropping due to destruction of the natural shrub cover for cropping through groundwater irrigation, while construction of too many water reservoirs and anicuts in the Aravalli hills has severely restricted stream function in the sandy plains (Kar, 2018). Elsewhere, several isolated hills are being cut up for stone chips to construct road networks, so much so that many smaller hills have almost vanished. Coarse sand along many ephemeral streams is being indiscriminately scooped out for building material, which is badly impacting the hydrology of this water-poor region. Although some course-correction at stakeholder level is also taking place, especially where the trade-off between technology-mediated 'development activities' and conservation practices is becoming too costly to sustain, the apathy towards landscape health for better ecosystem services is abysmal.

\section{Likely impacts of future climate change}

The negative impacts of above human modifications to landforms are getting exacerbated by recent anthropogenic climate change. Briefly, the climate simulation studies suggest that by the end of this century monsoon rainfall in western part of the desert may decline by $\sim 30 \%$, but pre-monsoon rain, which was almost absent earlier, may increase by $30-50 \%$. Temperature during summer and winter may rise by $3-5^{\circ} \mathrm{C}$, while the summer wind speed may increase by $10-20 \%$ (Rupakumar et al., 2006). To understand the impact of such changes on aridity and wind erosion, Kar (2012) calculated the moisture availability index (Im) and wind erosion index (WEI) in the region, using the IPCC AR-4 simulation data for A2 scenario. Simulation data from GFDL 2.01 and ECHAM 5.01 matched well with the observed values, and suggested that WEI might increase during the next decade and then fluctuate at a much higher level than at present till the end of the century, even though the past records show a gradual decline in summer wind speed and WEI from 1951 to 2000. Since then wind strength has started to show a slight increasing trend along the western and eastern margins (Kar, 2013), but the sand-reactivated areas have declined considerably over the first fifteen years of the present century (Kar, 2019). Additionally, a mid-May rain spell resulting from Western Disturbances is gradually becoming a boon for natural plant regeneration in the open rangelands and in effecting partial sand stabilization, while increased frequency of dust storms from the NW in early- to mid-summer with wet scavenging within 
the desert, is providing opportunities for silt trapping in shrub-covered lands. It will be interesting to monitor if the trends are sustained over the coming decades, and if the inhabitants are able to take bold land use decisions to gainfully utilise the emerging opportunity. The likely feedbacks from such evolving phenomena to the atmospheric and land surface processes might moderate the future climate. In the worst case scenario, the arid boundary may shift to the east of Jaipur by 2040 and drought frequency may increase. Since the satellite-derived atmospheric dust load pattern mimics the WEI pattern, the GCMderived higher WEI values during coming decades would mean higher atmospheric dust loads than at present, provided the predicted gradual increase in pre-monsoon rain does not suppress the dust emission (Kar, 2013, 2014). In case the dust transport from desert increases one may expect large-scale rainfall modification over northern India (Bollasina and Nigam, 2011).

\section{Cold Desert of Ladakh}

The cold desert of Ladakh lies to the north of the Zanskar Range in the Trans-Himalaya, where the Indian plate collided with the Eurasian plate and got subducted below the Kohistan-Ladakh arc along the southwestern margin of the Tibetan Plateau. Situated at an average elevation of $\sim 3500 \mathrm{~m}$ above mean sea level, the region experiences two different weather systems: one associated with the cool westerlies from the Mediterranean during October to March when snowfall takes place, and the other bringing warm and moist winds of the ISM from June to September, when some rains occur. The arid boundary roughly runs along the summit of the Zanskar Range, the land to its south having a semi-arid climate. The mean annual precipitation at Leh is $<150 \mathrm{~mm}$ (Lang and Barros, 2004), decreasing $\mathrm{NE}$ to $\sim 40 \mathrm{~mm}$. Strong winds blow throughout the year, but the stronger wind speed of $\sim 6 \mathrm{~m} / \mathrm{s}$ is recorded during March to June (Kumar et al., 2017). Palaeoclimatic reconstruction from the lacustrine sedimentary sequences in Ladakh reveal that all through the late Quaternary period stronger ISM favoured warm and wetter conditions with a tendency towards semi-arid condition, while the periods of stronger westerlies enhanced the aridity and cold climatic conditions (Demske et al., 2009).

\section{Present-day landforms}

Ladakh provides copybook examples of numerous glacial and periglacial landforms. In the active glacial areas it is common to find cirques with bergschrunds and arêtes near the summits, as well as hanging valleys and moraines (especially in the Zanskar Range, the Ladakh Range and the Eastern Karakoram), while the areas from where active glaciers have retreated reveal amphitheatre valleys, tors, roche moutonnees, drumlins, remnants of median, lateral and end moraines, etc. (Pant et al., 2005). In the areas where permafrost or seasonal frost occurs at ground and/or subsurface, a variety of periglacial features could be noticed. These include features of frostshattered congelifractates, frost-heaved congeliturbates, pingos, kettle holes, sorted stone polygons, etc. Normally, frost shattering during summer occurs to a depth of $5-10 \mathrm{~cm}$, but during winter it occurs to $50 \mathrm{~cm}$ or more depth. This process, along with the high lightning strikes in the area, fractures the bedrock over large parts of the periglacial domain, and makes available material for erosional agents. Chemical weathering of the igneous rocks at lower elevation produces finer debris (Dietsch et al., 2014). Small pingo mounds, related to subsurface seasonal ice wedges in the narrow alluvial plains of the Indus hinder cropping practices. Ladakh is also home to many fluvial, lacustrine and aeolian landforms, both present and past. Major fluvial landforms include the gravel-dominated alluvial fans along the hill slopes, strath terraces, valley-fill outwash terraces and lake-outburst terraces, as also the narrow sandy alluvial plains along the sluggish channels of the Indus and the Shyok. Typical aeolian landforms include the obstacle sand dunes along the hill slopes (also called the 'sand ramps', e.g., near Shey and Karu) and small crescentic dunes (e.g., in the Nubra valley). Examples of lacustrine features are the large and small lakes (e.g., Pangong Tso, Tso Kar). Chrono-stratigraphic records from the above landforms provide clues to the importance and time of endogenic and exogenic processes on the landscape development (Pant et al., 2005; Dortch et al., 2010; Sant et al., 2011; Bhutiyani, 2014; Dietsch et al., 2014; Juyal, 2014; Kumar et al., 2017; Kumar and Srivastava, 2017). At micro-level various physical and chemical weathering processes operate to either break down the solid material for the erosional agents, or to indurate the materials. The landforms appear to have their altitudinal niches. Thus, the glacial landforms are mostly found in the uppermost part of the mountainous terrain, followed at lower altitudes by the periglacial features, and then the fluvial, aeolian and lacustrine features near the valley bottom (Fig. 4).

Despite having an arid climate, Ladakh hosts the upstream reaches of one of the most important rivers of the Indian Subcontinent, the Indus, which originates from near Mt. Kailas in Tibet. Within Ladakh the Indus flows approximately in a SE to NW direction along a structural strike in the suture where the Indian and the Eurasian plates got locked, i.e., the Indus Suture Zone (ISZ). The river divides the barren and glaciated hill ranges in the north, composed essentially of the granodioritic batholiths of the Ladakh Range, the Khardung volcanics, the Pangong migmatites and the Karakoram crystalline complex, from the craggy subsidiary northern ranges of the Zanskar with colourful indurated molasses and flysch, as well as the sedimentaries and the crystallines of the lofty Zanskar Range and the High Himalaya further south (Thakur, 1983; Thakur and Misra, 1984). The Indus valley has evolved as an intermontane depression between the Ladakh Batholith and the Zanskar Range due to the persistent northward movement of the Indian plate since the early Eocene. Consequently it has suffered compressive deformation and progressive shortening (Garzanti and Van Haver, 1988).

The major tributary of the Indus in the district is the Shyok River from the north that flows almost parallel to it, and forms a barbed drainage pattern together with the Nubra River, suggesting river capture or back-tilting of the headwaters (Juyal, 2014). Smaller tributaries from the Zanskar Range in the south include the Zanskar and the Suru, which have deeply incised their beds in the Indus Molasse deposits along the ISZ, as the deposit has been subjected to a NE thrusting across the Indus valley since $14 \mathrm{Ma}$, resulting in a shortening of the Molasse width by $\sim 36 \mathrm{~km}$, uplift of the bedrock and base level adjustment by the streams across the deposit (Sinclair and Jaffey, 2001; Jamieson et al., 2004).

A number of glaciers occur in the region. Small cirque glaciers are numerous in the Ladakh Range, especially on its $\mathrm{N}$-facing slopes, as well as in the Zanskar Range, while the longer ones occur further north in the Eastern Karakoram Range (>10 km long) and the Central Karakoram Range ( $>70 \mathrm{~km}$ long), the latter hosting the Himalaya's longest glacier, the Siachen, despite the fact that precipitation in the region decreases from SW to NE (Wallis et al., 2016). This apparently 


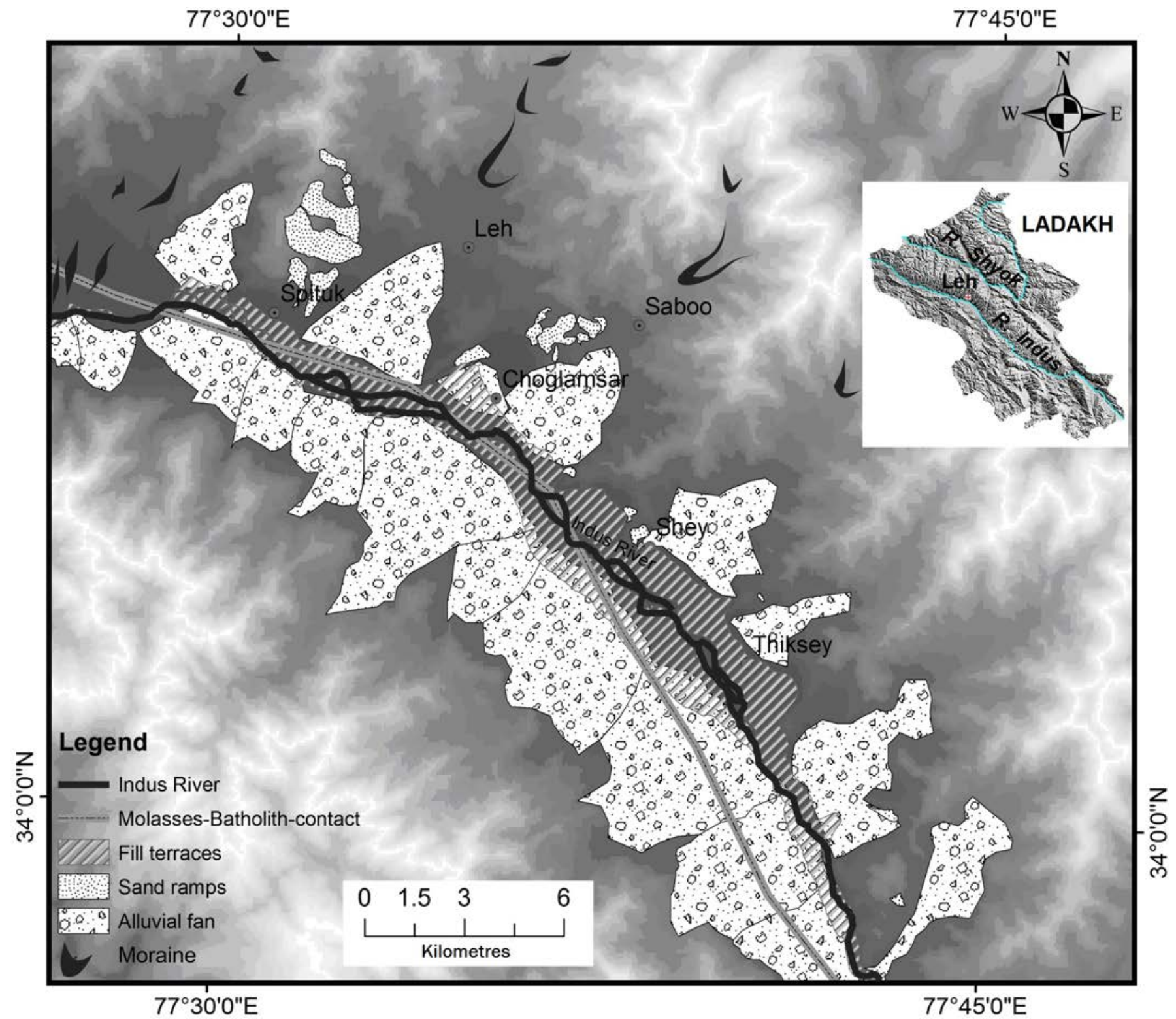

Figure 4. Dominant geomorphic features along the Indus River valley near Leh and its surroundings, as mapped from field studies and satellite image interpretation. The moraines are both lateral and terminal. Other notable landforms in the area (but not shown) include an amphitheatre valley at Leh, and a host of periglacial, glacio-fluvial, fluvial and lacustrine features. Background image is a SRTM-90m DEM. Inset map shows the major terrain configuration of Ladakh district, as seen on SRTM-90m DEM.

paradoxical glacier distribution pattern is related to the terrain elevation and terrain uplift rates, which increase progressively northward from the Indus valley in response to the gradual crustal shortening and thickening of sediments from the ISZ northward. It has triggered higher exhumation rates of the bedrocks in that direction (i.e., 0.09-0.47 mm/y in Ladakh Range to 0.65-0.70 mm/y in Eastern Karakoram) since 7.4 Ma (Wallis et al., 2016).

\section{Past glacial cycles}

Based on observations in the Shyok and the Nubra valleys, Dortch et al. (2010) identified three major glacial stages at $\sim 45 \mathrm{ka}$ (Deshkit-1), 81 ka (Deshkit-2) and 145 ka (Deshkit-3), and suggested that glacial advancement across the region was largely related to ISM precipitation. Compilation of results from several studies on moraine deposits, however, reveal ten periods of glacial advancement (i.e., glacial stages) in the Leh and Nubra valleys (Burbank and Fort, 1985; Owen et al., 2006; Dortch et al., 2010, 2013). The Indus valley glacial stage is one of the oldest, dated to $\sim 430$ ka (Owen et al., 2006). The moraines of Leh valley glacial stage are dated to $\sim 311$ ka. Deshkit-3 stage in Shyok valley, Kar glacial stage and Skardu glacial stage in Skardu valley (157 $\pm 13 \mathrm{ka}$; Seong et al., 2007) appear to be synchronous (Owen et al., 2006; Dortch et al., 2010). The Ladakh-4, Deshkit-2 and Pangong-2 glacial stages are dated to $\sim 80 \mathrm{ka}$, while the Bazgo glacial stage took place $\sim 61 \mathrm{ka}$. Deshkit-1 and Pangong-1 glacial stages are dated to 46 ka, Ladakh2 glacial stage to 20 ka (MIS-2), Ladakh-1 stage to $\sim 13.9 \mathrm{ka}$, and Ladakh cirque and Pangong cirque stages to $\sim 1.7$ and $\sim 0.4 \mathrm{ka}$, respectively (Owen et al., 2006; Dortch et al., 2010, 2013). In the Zanskar Range, evidence for four glacier advances was found (Sharma and Shukla, 2018). The oldest stage (SZS-4) was equivalent to MIS4, while SZS-3 occurred during LGM, and SZS-2 during a post-LGM 
glacial period (15.7-14.3 ka). SZS-1 has been dated to mid-Holocene ( $\sim 6 \mathrm{ka}$ ). Thus, the periods of glacial advancement in the region are now found not to be restricted by exclusive summer or winter precipitations, but to the relative strength of both climatic forces. Nagar et al. (2013) found evidence for extensive glaciation in Nubra valley during the LGM, which was related to the winter precipitation from the westerlies.

\section{Valley fill sequences}

The glacial events generated enormous sediments within the region, which got slowly transported downslope by the streams as debris flow, outwash fan and valley filling (Fig. $5 \mathrm{~A}$ and $\mathrm{B}$ ). As a result, the valley floors started to gradually fill up along the Indus and its tributaries from both north and south, and subsequently channel incision also took place through those in-filled valleys (Burbank et al., 1996; Leland et al., 1998; Phartiyal et al., 2013; Blöthe et al., 2014; Kumar and Srivastava, 2017; Jonell et al., 2018). At least three pulses of aggradation have been identified from sediment dating, centred at $\sim 52 \mathrm{ka}, \sim 28 \mathrm{ka}$, and 16 ka (Blöthe et al., 2014; Kumar and Srivastava, 2017). The aggradation and incision processes divided the Indus valley into two segments: (1) from Nyoma to Leh, characterized by one level of channel filling, and (2) from Leh to Dah Hanu, characterized by one fill and one strath terrace. Apart from the above, an older filling event along the Indus at $\sim 200 \mathrm{ka}$ and a younger filling at $\sim 8-6 \mathrm{ka}$ in the Zanskar rivers were also identified (Blöthe et al., 2014; Jonell et al., 2018). In the Karakoram, valley filling along the Tangste River took place during intensified monsoon at $48 \mathrm{ka}$ and 30-21 ka, especially through glacio-fluvial, fluvial and lacustrine sedimentation (Phartiyal et al., 2015).

\section{Lacustrine records}

Dating of several lacustrine deposits revealed an interesting sedimentation pattern. Lacustrine deposits at Spituk is dated to 50-30 ka, while that at Lamayuru (Fig. $6 \mathrm{~A}$ ) is >35 ka (Kotlia et al., 1997; Phartiyal et al., 2005). A string of palaeolake deposits along the downstream reaches of the Indus between Nimu and Batalik revealed dates of $\sim 11 \mathrm{ka}$ (at Saspol), 17-14 ka (Rizong), 15-5 ka (Khalsi), 11 ka (Achinathang) and 14-6 ka (Biamah), which suggested that the lake levels rose from $35 \mathrm{ka}$ to $5 \mathrm{ka}$, but also that the rise in temperature and monsoon influences might not have been consistent over the period (Nag and Phartiyal, 2015).

\section{Sand ramps and their palaeoclimatic records}

The sand ramps of Ladakh (Fig 6 B) provide a composite record of aeolian deposition, hillslope debris and fluvial processes. Most of these occur along the hill slopes bordering the Indus, especially at Spituk, Leh, Saboo, Choglamsar, Thiksey, Shey and Stakna. Aeolian
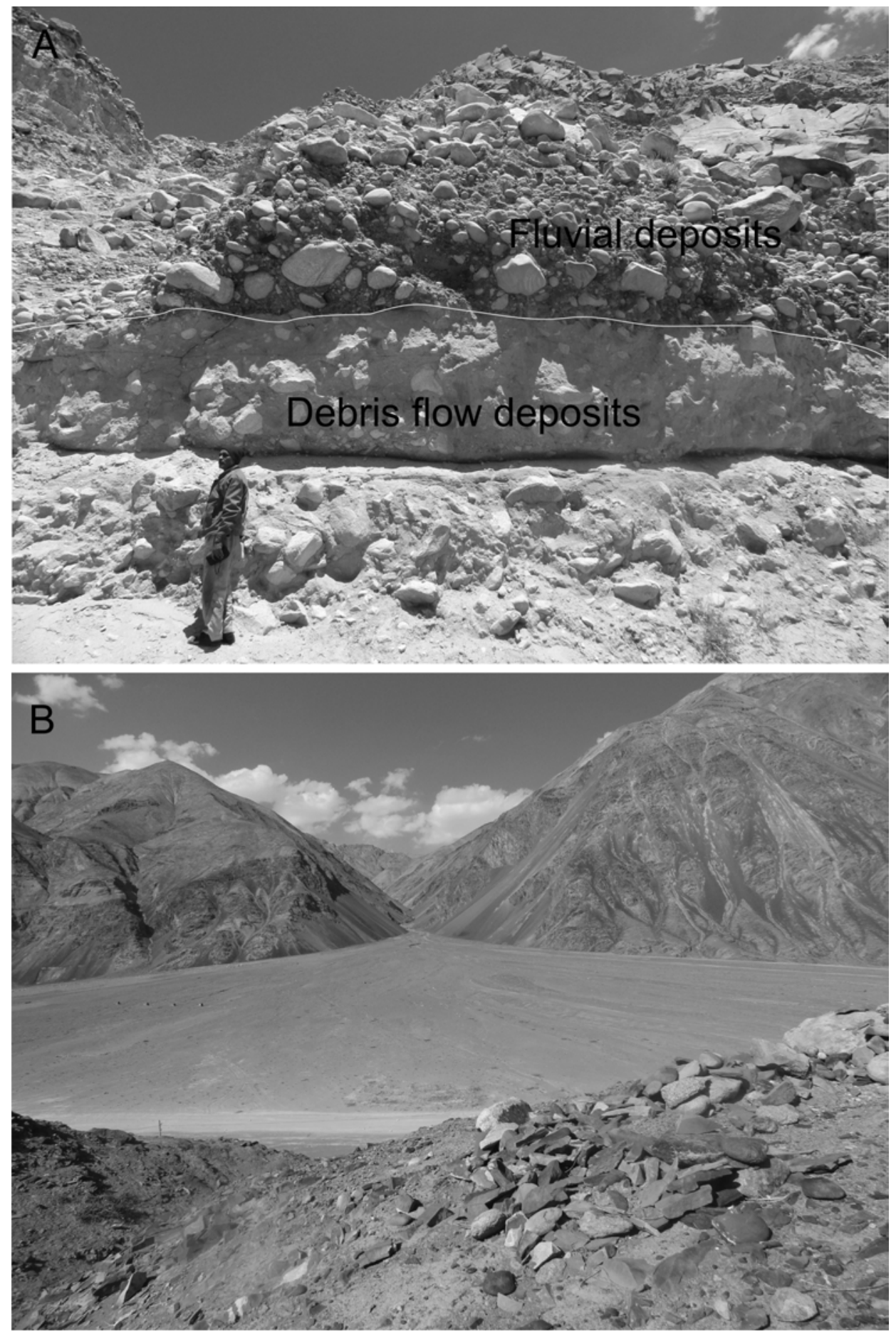

Figure 5. (A) A valley fill sequence showing debris flow and fluvial deposits along the Indus River near Mahe village. (B) A panoramic view of the alluvial fan at Nurla. 
sand is sourced from the adjacent Indus floodplain, especially during the hot and dry months of March-June when strong wind winnows the finer sand particles from the floodplain to deposit them along the hill slopes, especially where vegetation cover is low. Thus, the process efficiency depends on ample sediment availability, strong winds, and low vegetation cover (Kumar et al., 2017). Hillslope runoff during the subsequent summer tends to partly wash down the aeolian sand and deposit coarser fluvial materials from upslope on them. The process is continuing through the millennia, leading to mm-scale stratification of aeolian and fluvial deposits in the ramps. Thicker overall deposits of aeolian/fluvial deposits (but with smaller stratifications within) provide evidence for the duration of the enabling drier or wetter climate. Sedimentological analysis indicates increased precipitation and intra-dune lake formation at places during wetter climatic phases.

Dating of sediments in the sand ramps at Shey, Choglamsar, Saboo and Spituk reveal two major aeolian accretion phases: Phase-I during 25-15 ka and Phase-II 12-8 ka (Fig 7; Kumar et al., 2017). An older aeolian phase at $\sim 44 \pm 3$ ka was identified from a sequence near Shey. Phase-I (25-15 ka) includes several short-term, relatively wetter spells punctuating the overall dry phase of the Last Glacial Maxima (LGM). These increased the threshold moisture and
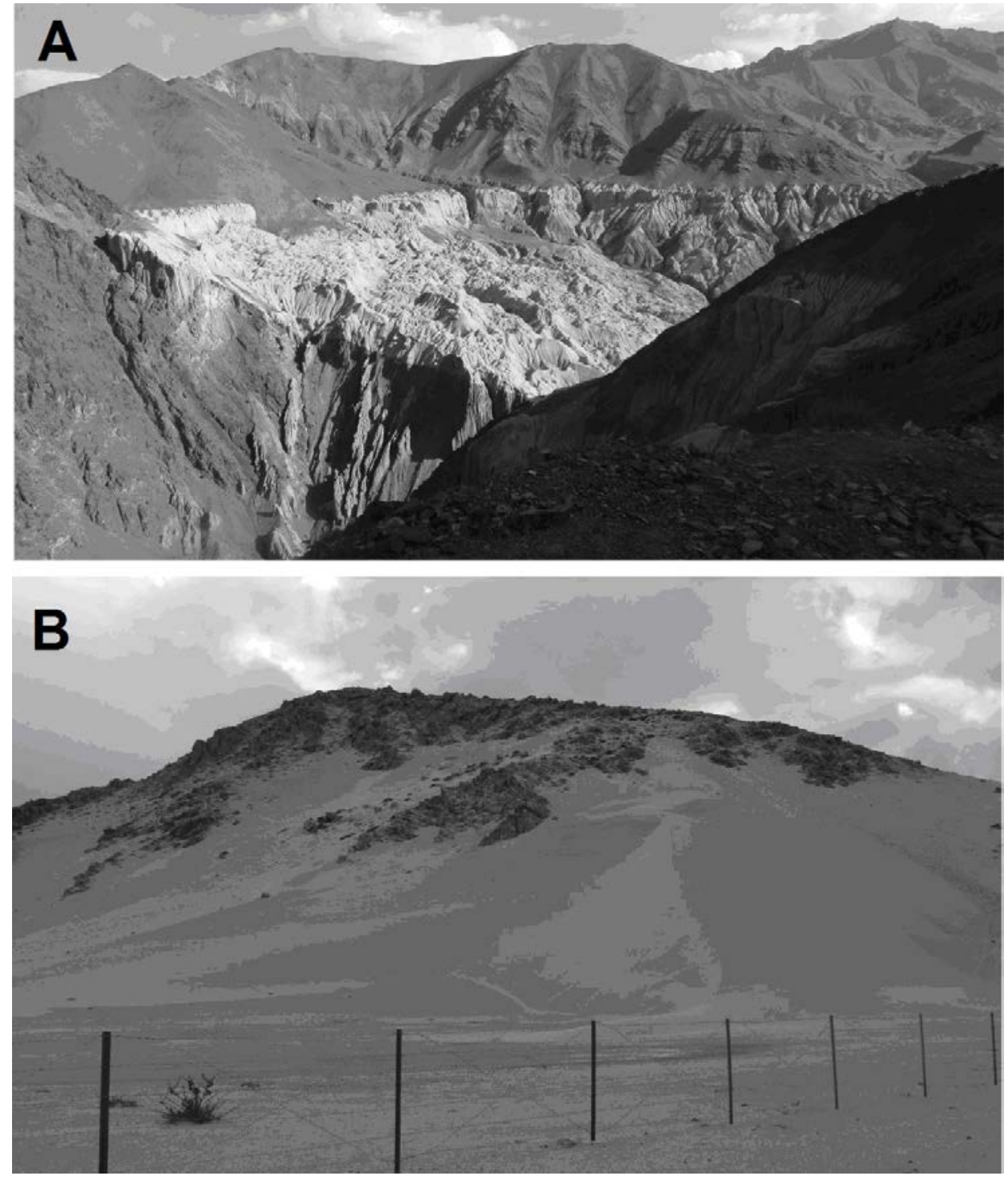

Figure 6. (A) A landslide-dammed palaeolake deposit at Lamayuru. (B) A sand ramp at Nyoma.

possibly increased the plant cover for sand trapping. Studies on glacial moraines in Ladakh showed glacial advances during phase-I (Owen et al., 2006, 2008; Demske et al., 2009; Dortch et al., 2010, 2013; Phartiyal et al., 2013; Owen and Dortch, 2014). Phase-I sand accumulation has also been observed in the Chinese loess records (Porter, 2001).

The high occurrence of slope-wash and channel gravels in PhaseII (12-8 ka) sediments and the intra-dune lake deposits ( 12 ka at Shey) suggest an overall wetter climate during their formation. The glacial and Tso Kar lake records suggest glacial expansion at 10.6 \pm 0.7 ka and 8.3 \pm 0.5 ka (Owen et al., 2006; Dortch et al., 2013), and an arid phase during 13.5-11.5 ka and 8.5-7.0 ka (Demske et al., 2009; Wünnemann et al., 2010).

\section{Comparison with past aeolian phases in Thar Desert}

To understand the climates of sand accumulation in the Thar Desert and the Ladakh Himalaya, their chronologies were compared with the chronologies for Guliya ice core (Thompson et al., 1997), effective moisture for the Himalaya (Herzschuh et al., 2006) and the Indian
Ocean sea surface temperature (SST) reconstructed from the $\mathrm{Mg} / \mathrm{Ca}$ values of planktonic foraminifer Globigerinoidesruber (Saraswat et al., 2005). It reveals quite contrasting climatic phases for the two regions (Fig 7). While aeolian sand accretion in the Thar Desert took place mainly during the strengthening phases of the SW monsoon, that in Ladakh took place mainly during the cold arid phases.

\section{Neotectonic activities}

Information on neotectonic activities in Ladakh is scarce and spatially discordant. Dietsch et al. (2014) suggest that Ladakh Range is quiescent since mid-Miocene, while Phartiyal et al. (2015) inform that the Tangste river valley preserves some evidence for neotectonic activities along the Karakoram Fault. Along the Stok thrust on the SW margin of the Indus valley Sinclair et al. (2017) have calculated from terrace dating and structural mapping, a horizontal displacement rate of $\sim 0.21 \mathrm{~m}$ per ka since $45 \mathrm{ka}$, which has constricted the valley by $\sim 0.1 \mathrm{~m}$ per ka and migration of the river channel towards the NE direction. Evidence for recent tectonic activities has also been gathered from the strath terraces along the Indus and the Zanskar (Blöthe et al., 2014; Munack et al., 2014; Kumar and Srivastava, 2017). 


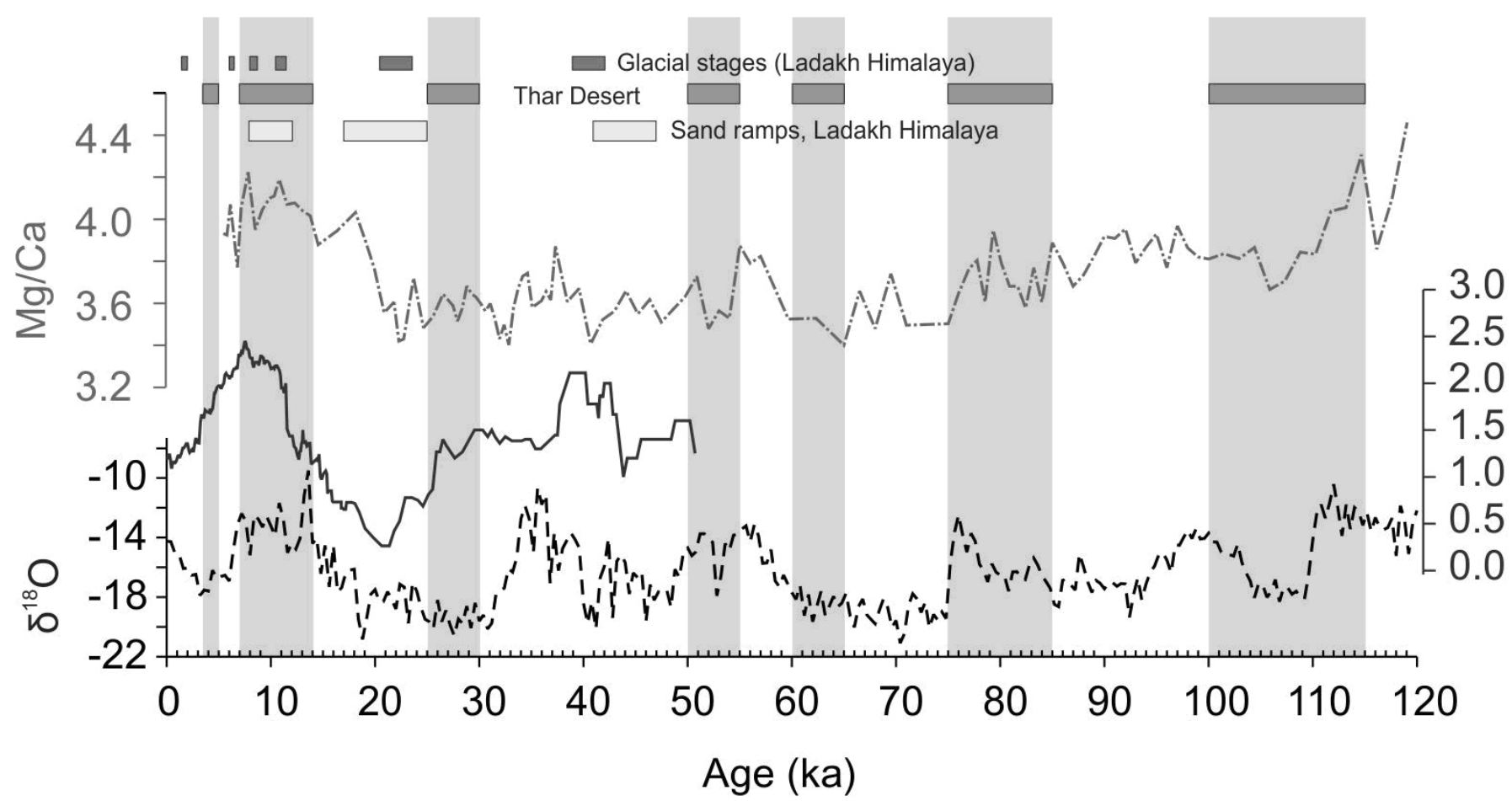

Figure 7. The proxy data for paleoclimate is compared with the sand accumulation for both cold and hot deserts in India. The dashed black line indicates atmospheric temperature changes from Guliya ice core (Thompson et al., 1997), the solid black line shows effective moisture (Herzschuh et al., 2006) for Tibetan Plateau, and the dash and dot grey line indicates sea surface temperature in the Arabian Sea, reconstructed from Globigerinaruber (white) Mg/Ca ratio (Saraswat et al., 2005). The top-most bars on glacial stages represent the timing of glacial extension in Ladakh (Owen et al., 2006; Phartiyal et al., 2013). The bars on Thar Desert represent the timing of sand accumulation in Thar Desert (Kar, et al., 2001, 2004; Singhvi and Kar, 2004; Kumar et al., 2017), while the bars on sand ramps in Ladakh Himalaya indicate the periods of sand accumulation in Ladakh.

\section{Present-day human impact and likely future}

As development activities are increasing in Ladakh, incidence of encroachments on the natural systems are also increasing. Construction of roads and buildings on unstable slopes, or across the ephemeral drainage pathways on the fan deposits, has made the landscape more vulnerable to landslide, sheetwash and flooding, with consequent damages to the infrastructures. A recent example is the catastrophic flood in Leh and surrounding areas during August 2010, which was related to a cloud-burst (Juyal, 2010; Ziegler et al., 2016). Although such high rainfall events takes place at periodic intervals, the recent construction spree on shallow channels of the alluvial fans and along the debris-covered hill slopes started to block the natural drainage system on the alluvial fan deposits, especially around Leh and Choglamsar. The high run-off generated during the cloud-burst got obstructed by the new infrastructures and, finding no natural escape routes, destroyed whatever came downslope. Added to this problem is the impact of recent anthropogenic climate change that shows a warming trend with reduced number of days of precipitation, but with increased incidence of high-intensity rains. Such a scenario may lead to increased incidence of drought and flood (Chevuturi et al., 2018). Geo-hazard mapping, risk assessment and preparedness may help to mitigate such events (Hart and Hearn, 2018).

\section{Conclusions}

It is evident from the above review that the arid landscapes of
Thar Desert and Ladakh provide very interesting clues to their respective evolutionary histories, but that the landscapes are very dissimilar in the two areas, despite the fact that the landscape histories of both the areas are related to the fluctuating SW monsoon. While Thar Desert is part of the hot arid region, and has its landforms developed on a stable platform, Ladakh is a part of the cold arid region where the terrain is mountainous. Aeolian processes are dominant in Thar Desert, but glacial and periglacial processes dominate in Ladakh. Even the past climatic phases for aeolian process acceleration in the two deserts were dissimilar during the past. The landscape of both the regions, however, is vulnerable to excessive human pressure and future climate change, which may lead to accelerated soil erosion and land quality degradation. This calls for judicious use of the land resources for long-term sustainability.

\section{Acknowledgement}

Anil Kumar acknowledges the help and guidance received from Director, Wadia Institute of Himalayan Geology, Dehradun.

\section{References}

Anonymous. 1874, Notes on the lost river of the Indian Desert. The Calcutta Review, v. 59, pp.3-29.

Ashwal, L.D., Solanki, A.M., Pandit, M.K., Corfu, F., Hendriks, B.W.H., Burke, K., and Torsvik, T.H., 2013, Geochronology and geochemistry of Neoproterozoic Mt. Abu granitoids, NW India: 
Regional correlation and implications for Rodina paleogeography. Precambrian Research, v. 236, pp. 265-281.

Bhutiyani, M.R., 2014, The Siachen Glacier: The second longest glacier outside the polar regions. In: V.S. Kale (ed.), Landscapes and Landforms of India, Springer, Dordrecht, pp. 105-113.

Blöthe, J.H., Munack, H., Korup, O., Fülling, A., Garzanti, E., Resentini, A., and Kubik, P.W., 2014, Late Quaternary valley infill and dissection in the Indus River, western Tibetan Plateau margin. Quaternary Science Reviews, v. 94, pp.102-119.

Bollasina, M., and Nigam, S., 2011, Modeling of regional hydroclimate change over the Indian Subcontinent: Impact of the expanding Thar Desert. Jounal of Climate, v. 24, pp. 3089-3106.

Burbank, D.W., and Fort, M.B., 1985, Bedrock control on glacial limits: Examples from the Ladakh and Zanskar Ranges, northwestern Himalaya, India. Journal of Glaciology, v. 31(108), pp.143-149.

Burbank, D.W., Leland, J., Fielding, E., Anderson, R.S., Brozovic, N., Reid, M.R., and Duncan, C., 1996, Bedrock incision, rock uplift and threshold hillslopes in the northwestern Himalayas. Nature, v. 379(6565), p.505.

Caley, T., Roche, D.M., and Renssen, H., 2014, Orbital Asian summer monsoon dynamics revealed using an isotope-enabled global climate. Nature Communications, v. 5, pp.5371, DOI:10.1038/ ncomms6371.

Chevuturi, A., Dimri, A.P., and Thayyen, R.J., 2018, Climate change over Leh (Ladakh), India. Theoretical and Applied Climatology, v. 131, pp.531-545.

Clift, P.D., Carter, A., Giosan, L., Durcan, J., Duller, G.A.T., Macklin, M.G., Alizai, A., Tabrez, A.R., Danish, M., VanLaningham, S., and Fuller, D.Q., 2012, U-Pb zircon dating evidence for a Pleistocene Sarasvati River and capture of the Yamuna River. Geology, v. 40, pp. 211-214.

Davis, J.K., Meert, J.G., and Pandit, M.K., 2014, Paleomagnetic analysis of the Marwar Supergroup, Rajasthan, India and proposed interbasinal correlations. Journal of Asian Earth Sciences, v. 91, pp. 339-351.

Demske, D., Tarasov, P.E., Wünnemann, B., and Riedel, F., 2009, Late glacial and Holocene vegetation, Indian monsoon and westerly circulation in the Trans-Himalaya recorded in the lacustrine pollen sequence from Tso Kar, Ladakh, NW India. Palaeogeography, Palaeoclimatology, Palaeoecology, v. 279, pp.172-185.

Dhir, R.P., Singhvi, A.K., Andrews, J.E., Kar, A., Sareen, B.K., Tandon, S.K., Kailath, A., and Thomas, J.V., 2010, Multiple episodes of aggradation and calcrete formation in Late Quaternary aeolian sands, central Thar Desert, Rajasthan, India. Journal of Asian Earth Science, v. 37, pp.10-16.

Dietsch, C., Dortch, J.M., Reynhout, S.A., Owen, L.A., and Caffee, M.W., 2014, Very slow erosion rates and landscape preservation across the southwestern slope of Ladakh Range, India. Earth Surface Processes and Landforms, v. 40, pp.389-402.

Dortch, J.M., Owen, L.A., and Caffee, M.W., 2010, Quaternary glaciation in the Nubra and Shyok valley confluence, northernmost Ladakh, India. Quaternary Research, v. 74, pp.132-144.

Dortch, J.M., Owen, L.A., and Caffee, M.W., 2013, Timing and climatic drivers for glaciation across semi-arid western Himalayan-Tibetan orogen. Quaternary Science Reviews, v. 78, pp.188-208.

Dutt, S., Gupta, A.K., Clemens, S.C., Cheng, H., Singh, R.K., Kathayat, G., and Edwards, R.L., 2015, Abrupt changes in Indian summer monsoon strength during 33,800 to 5500 years B.P. Geophysical Research Letters, v. 42, pp.5526-5532.

Garzanti, E., and Van Haver, T., 1988, The Indus clastics: forearc basin sedimentation in the Ladakh Himalaya (India). Sedimentary
Geology, v. 59, pp.237-249.

Ghose, B., Kar, A., and Husain, Z., 1979, The lost courses of the Saraswati River in the Great Indian Desert - New evidence from Landsat imagery. The Geographical Journal, v. 145, pp.446-451.

Goudie, A., Allchin, B., and Hegde, K.T.M., 1973, The former extensions of the Great Indian Sand Desert. The Geographical Journal, v. 139, pp.243-257.

Groll, N., Widmann, M., Jones, J.M., Kaspar, F., and Lorenz, S.J., 2005, Simulated relationships between regional temperatures and large-scale circulation: 125 kyr BP (Eemian) and the Preindstrial Period. Journal of Climate, v. 18, pp.4032-4045.

Hart, A.B., and Hearn, G.J., 2018, Mappinggeohazards in the watersheds above Leh, Ladakh: The use of publicly-available remote sensing to assist risk management. International journal of disaster risk reduction, v. 31, pp.789-798.

Heron, A.M. 1953, Geology of Central Rajputana. Memoirs of the Geological Survey of India, v. 79, 339p.

Herzschuh, U., 2006, Palaeo-moisture evolution in monsoonal Central Asia during the last 50,000 years. Quaternary Science Reviews, v. 25, pp.163-178.

Hobley D.J., Sinclair, H.D. and Mudd, S.M., 2012, Reconstruction of a major storm event from its geomorphic signature: The Ladakh floods, 6 August 2010. Geology, doi:10.1130/G32935.1.

Jain, M., Tandon, S.K., Singhvi, A.K., Mishra, S., and Bhatt, S.C., 2005, Quaternary alluvial stratigraphical development in a desert setting: A case study from the Luni River basin, Thar Desert of western India. International Association of Sedimentology Special Publication, v. 35, pp.349-371.

Jamieson, S.S.R., Sinclair, H.D., Kirstein, L.A., and Purves, R.S., 2004, Tectonic forcing of longitudinal valleys in the Himalaya: morphological analysis of the Ladakh Batholith, North India. Geomorphology, v. 58(1-4), pp.49-65.

Jonell, T.N., Owen, L.A., Carter, A., Schwenniger, J.L., and Clift, P.D., 2018, Quantifying episodic erosion and transient storage on the western margin of the Tibetan Plateau, upper Indus River. Quaternary Research, v. 89, pp.281-306.

Juyal, N., 2010, Cloud burst-triggered debris flows around Leh. Current Science, v. 99, pp.1166-1167.

Juyal, N., 2014, Ladakh: the high-altitude Indian cold desert. In: V.S. Kale (ed.), Landscapes and Landforms of India, Springer, Dordrecht, pp.115-124.

Juyal, N., Kar, A., Rajaguru, S.N., and Singhvi, A.K., 2003, Luminescence chronology of aeolian deposition during the Late Quaternary on the southern margin of Thar Desert, India. Quaternary International, v. 104, pp. 87-98.

Kar, A., 1988, Possible neotectonic activities in the Luni-Jawai plains, Rajasthan. Journal of the Geological Society of India, v. 32, pp.522-526.

Kar, A., 1990, A stream trap hypothesis for the evolution of some saline lakes in the Indian Desert. ZeitschriftfurGeomorphologie, v. 34, pp.37 47.

Kar, A., 1993a, Aeolian processes and bedforms in the Thar Desert. Journal of Arid Environments, v. 25, pp.83-96.

Kar, A., 1993b, Present day geomorphic processes as key to the reconstruction of Quaternary landform history in Thar Desert. Journal of the Geological Society of India, v. 41, pp.513-517.

Kar, A., 1995, Geomorphology of arid western India. Memoir of the Geological Society of India, v.32, pp.168-190.

Kar, A., 2012, GCM-derived future climate of arid western India and implications for land degradation. Annals of Arid Zone, v. 51, pp. 147-169.

Kar, A., 2013, Quantification of aeolian bedform and process parameters in Thar Desert for earth surface dynamics. Annals of Arid Zone, v. 52, pp.181-207. 
Kar, A., 2014, The Thar or the Great Indian Sand Desert. In: V.S. Kale (ed.), Landscapes and Landforms of India, Springer, Dordrecht, pp. 79-90.

Kar, A., 2018, Desertification: Causes and effects. In: D. Bartlett and R.P. Singh (eds.), Exploring Natural Hazards: A Case Study Approach. CRC Press, Taylor \& Francis Group, Boca Raton, USA, pp.159-205.

Kar, A., 2019, Natural resource vulnerability under climate change scenarios in arid western India. In: Program and Abstracts, Satellite Symposia, $13^{\text {th }}$ International Conference on Development of Drylands (11-14 February, 2019), Central Arid Zone Research Institute, Jodhpur, pp.80.

Kar, A., Felix, C., Rajaguru, S.N., and Singhvi, A.K., 1998, Late Holocene growth and mobility of a transverse dune in the Thar Desert. Journal of Arid Environments, v. 38, pp.175-185.

Kar, A., and Ghose, B., 1984, The Drishadvati River system of India: An assessment and new findings. The Geographical Journal, v. 150, pp.221 229.

Kar, A., Singhvi, A.K., Rajaguru, S.N., Juyal, N., Thomas, J.V., Banerjee, D., and Dhir, R.P., 2001, Reconstruction of the late Quaternary environment of the lower Luni plains, Thar Desert, India. Journal of Quaternary Science, v. 16, pp.61-68.

Kar, A., Singhvi, A.K., Juyal, N., and Rajaguru, S.N., 2004, Late Quaternary aeolian sedimentation history of the Thar Desert. In: H.S. Sharma, Savindra Singh and Sunil De (eds.), Geomorphology and Environment. ACB Publications, Kolkata, pp.105-122.

Kotlia, B.S., Shukla, U.K., Bhalla, M.S., Mathur, P.D., and Pant, C.C., 1997, Quaternary fluvio-lacustrine deposits of the Lamayuru Basin, Ladakh Himalaya: preliminary multidisciplinary investigations. Geological Magazine, v. 134, pp.807-812.

Krishnan, A. and Thanvi, K.P., 1977, Quantification of rainfall in different regions of western Rajasthan. Annals of Arid Zone, v.16, pp.185-194.

Kumar, A., and Srivastava, P., 2017, The role of climate and tectonics in aggradation and incision of the Indus River in the Ladakh Himalaya during the late Quaternary. Quaternary Research, v. 87, pp.363-385.

Kumar, A., Srivastava, P., and Meena, N.K., 2017, Late Pleistocene aeolian activity in the cold desert of Ladakh: a record from sand ramps. Quaternary International, v. 443, pp.13-28.

Lang, T.J., and Barros, A.P., 2004, Winter storms in the central Himalayas. Journal of the Meteorological Society of Japan. Ser. II, v. 82(3), pp.829-844.

Leland, J., Reid, M.R., Burbank, D.W., Finkel, R., and Caffee, M., 1998, Incision and differential bedrock uplift along the Indus River near Nanga Parbat, Pakistan Himalaya, from 10Be and 26Al exposure age dating of bedrock straths. Earth and Planetary Science Letters, v. 154, pp. 93-107.

Meert, J.G., Pandit, M.K., Pradhan, V.R., Banks, J., Sirianni, R., Stoud, M., Newstead, B., and Gifford, J., 2010, Precambrian crustal evolution of Peninsular India: A 3.0 billion year odyssey. Journal of Asian Earth Sciences, v. 39, pp. 483-515.

Munack, H., Korup, O., Resentini, A., Limonta, M., Garzanti, E., Blöthe, J.H., Scherler, D., Wittmann, H., and Kubik, P.W., 2014, Postglacial denudation of western Tibetan Plateau margin outpaced by long-term exhumation. Geological Society of America Bulletin, v. 126, pp.1580-1594.

Nag, D., and Phartiyal, B., 2015, Climatic variations and geomorphology of the Indus River valley, between Nimo and Batalik, Ladakh (NW Transhimalayas) during late Quaternary. Quaternary International, v. 371, pp.87-101.

Nagar, Y.C., Ganju, A., Satyawali, P.K., and Juyal, N., 2013, Preliminary optical chronology suggests significant advance in Nubra valley glaciers during the Last Glacial Maximum. Current
Science, pp. 96-101.

Owen, L.A., Caffee, M.W., Bovard, K.R., Finkel, R.C., and Sharma, M.C., 2006, Terrestrial cosmogenic nuclide surface exposure dating of the oldest glacial successions in the Himalayan orogen: Ladakh Range, northern India. Geological Society of America Bulletin, v. 118, pp.383-392.

Owen, L.A., Caffee, M.W., Finkel, R.C., and Seong, Y.B., 2008, Quaternary glaciation of the Himalayan-Tibetan orogen. Journal of Quaternary Science, v. 23, pp.513-531.

Owen, L.A., and Dortch, J.M., 2014, Nature and timing of Quaternary glaciation in the Himalayan-Tibetan orogen. Quaternary Science Reviews, v. 88, pp.14-54.

Pant, R.K., Phadtare, N.R., Chamyal, L.S., and Juyal, N., 2005, Quaternary deposits in Ladakh and Karakoram Himalaya: a treasure trove of the palaeoclimate records. Current Science, v. 88, pp.1789-1798.

Phartiyal, B., Sharma, A., and Kothari, G.C., 2013, Existence of Late Quaternary and Holocene lakes along the River Indus in Ladakh Region of Trans Himalaya, NW India: implications to climate and tectonics. Chinese Science Bulletin, v. 58(142), p.e155.

Phartiyal, B., Sharma, A., Upadhyay, R., and Sinha, A.K., 2005, Quaternary geology, tectonics and distribution of palaeo-and present fluvio/glacio lacustrine deposits in Ladakh, NW Indian Himalaya - a study based on field observations. Geomorphology, v. 65 , pp.241-256

Phartiyal, B., Singh, R., and Kothyari, G.C., 2015, Late-Quaternary geomorphic scenario due to changing depositional regimes in the Tangtse Valley, Trans-Himalaya, NW India. Palaeogeography, palaeoclimatology, palaeoecology, v. 422, pp.11-24.

Porter, S.C., 2001, Chinese loess record of monsoon climate during the last glacial-interglacial cycle. Earth-Science Reviews, v. 54, pp.115-128.

Roy, P.D., and Singhvi, A.K., 2016, Climate variation in the Thar Desert since the Last Glacial Maximum and evaluation of the Indian monsoon. TIP Revista Especializadaen Ciencias QuimicoBiologicas, v. 19, pp.32-44.

Rupakumar, K., Sahai, A.K., Krishna Kumar, K., Patwardhan, S.K., Mishra, P.K., Revadekar, J.V., Kamala, K., and Pant, G.B., 2006, High-resolution climate change scenarios for India for the $21^{\text {st }}$ century. Current Science, v. 90, pp.334-345.

Sant, D.A., Wadhawan, S.K., Ganjoo, R.K., Basavaiah, N., Sukumaran, P., and Bhattacharya, S., 2011, Morphostratigraphy and palaeoclimate appraisal of the Leh Valley, Ladakh Himalayas, India. Journal of the Geological Society of India, v. 77, pp.499510.

Saraswat, R., Nigam, R., Weldeab, S., Mackensen, A., and Naidu, P.D., 2005, A first look at past sea surface temperatures in the equatorial Indian Ocean from $\mathrm{Mg} / \mathrm{Ca}$ in foraminifera. Geophysical Research Letters, v. 32(24).

Seong, Y.B., Owen, L.A., Bishop, M.P., Bush, A., Clendon, P., Copland, L., Finkel, R., Kamp, U., and Shroder Jr, J.F., 2007, Quaternary glacial history of the Central Karakoram. Quaternary Science Reviews, v. 26, pp.3384-3405.

Sharma, S., and Shukla, A.D., 2018, Factors governing the pattern of glacier advances since the Last Glacial Maxima in the transitional climate zone of the Southern Zanskar Ranges, NW Himalaya. Quaternary Science Reviews, v. 201, pp.223-240.

Shin, S-I., Lin, Z., Otto-Bliesner, B., Brady, E.C., Kutzbach, J.E., and Harrison, S.P., 2003, A simulation of the Last Glacial Maximum climate using the NCAR-CCSM. Climate Dynamics, v. 20, pp.127-151.

Sinclair, H.D., and Jaffey, N., 2001, Sedimentology of the Indus Group, Ladakh, northern India: Implications for the timing of initiation of the palaeo-Indus River. Journal of the Geological 
Society, London, v. 158, pp.151-162.

Sinclair, H.D., Mudd, S.M., Dingle, E., Hobley, D.E.J., Robinson, R., and Walcott, R., 2017, Squeezing river catchments through tectonics: Shortening and erosion across the Indus Valley, NW Himalaya. Bulletin, v. 129, pp.203-217.

Singh, A., Paul, D., Sinha, R., Thomsen, K.J., and Gupta, S., 2016, Geochemistry of buried river sediments from Ghaggar Plains, NW India: Multi-proxy records of variations in provenance, paleoclimate, and paleovegetation patterns in the late Quaternary. Palaeogeography, Palaeoclimatology, Palaeoecology, v. 449, pp.85-100.

Singh, G., Joshi, R.D., Chopra, S.K., and Singh, A.B., 1974, Late Quaternary history of vegetation and climate of the Rajasthan desert, India. Philosophical Transactions of the Royal Society, v. 267B, pp.467-501.

Singhvi, A.K., and Kar, A., 2004, The aeolian sedimentation record of the Thar Desert. Proceedings Indian Academy of Sciences (Earth \& Planetary Science), v. 113, pp.371-401.

Sinharoy, S., Malhotra, G., and Mohanty, M., 1998, Geology of Rajasthan. Geological Society of India, Bangalore, 278 p.

Thakur, V.C., 1983, Palaeotectonic evolution of Indus-Tsangpo suture zone in Ladakh and southern Tibet. Geology of Indus Suture Zone of Ladakh. Wadia Institute of Himalayan Geology, Dehra Dun, India, pp.195-204.

Thakur, V.C., and Misra, D.K., 1984, Tectonic framework of the Indus and Shyok suture zones in eastern Ladakh, northwest Himalaya. Tectonophysics, v. 101, pp.207-220.

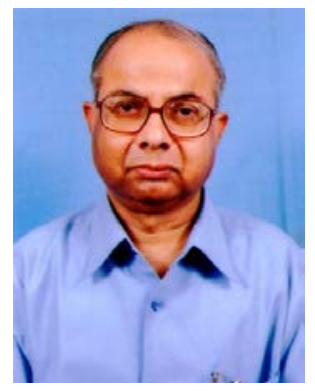

Dr. Amal Kar was Principal Scientist and Head, Natural Resources \& Environment Division at Central Arid Zone Research Institute, Jodhpur, from where he retired in mid-2012. He was also a Visiting Professor at the University of Tokyo (2001), and a short-period Consultant to the UN on desertification. His research includes desert geomorphology, desertification, geomatics applications, etc. He was also an Editor of Annals of Arid Zone, Jodhpur, and Sustainability Science, Springer. He now lives in Kolkata as an independent researcher.
Thompson, L.O., Yao, T., Davis, M.E., Henderson, K.A., MosleyThompson, E., Lin, P.N., Beer, J., Synal, H.A., Cole-Dai, J., and Bolzan, J.F., 1997, Tropical climate instability: The last glacial cycle from a Qinghai-Tibetan ice core. Science, v. 276, pp.18211825.

Wadhawan, S.K., 2018, Palaeogene - Neogene tectonics and continental aggradational basins in north-western India: Implications for geological evolution of Thar Desert. I, pp. 151n: Sunil Bajpai, S.C. Tripathi and Vandana Prasad (eds.), The Indian Paleogene. Springer, pp.151-166.

Wallis, D., Carter, A., Phillips, R.J., Parsons, A.J., and Searle, M.P., 2016, Spatial variation in exhumation rates across Ladakh and the Karakoram: New apatite fission track data from the Eastern Karakoram, NW India. Tectonics, v. 35(3), pp.704-721.

Wünnemann, B., Demske, D., Tarasov, P., Kotlia, B.S., Reinhardt, C., Bloemendal, J., Diekmann, B., Hartmann, K., Krois, J., Riedel, F., and Arya, N., 2010, Hydrological evolution during the last 15 kyr in the Tso Kar lake basin (Ladakh, India), derived from geomorphological, sedimentological and palynological records. Quaternary Science Reviews, v. 29, pp.1138-1155.

Ziegler, A.D., Cantarero, S.I., Wasson, R.J., Srivastava, P., Spalzin, S., Chow, W.T., and Gillen, J., 2016, A clear and present danger: Ladakh's increasing vulnerability to flash floods and debris flows. Hydrological Processes, v. 30, pp.4214-4223.

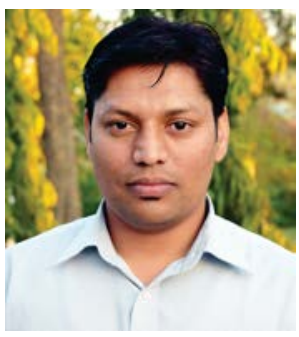

Dr. Anil Kumar is a Scientist at Wadia Institute of Himalaya Geology, Dehradun. He worked on Quaternary landscape evolution along the Indus and Zanskar rivers and on paleoflood records from the Indus and Brahmaputra rivers. His broad area of research is climate-tectonic interaction and landform evolution. His work on the sand ramps of the Ladakh Himalaya discusses the sedimentology, geomorphology and climate parameters in the formation of sand ramps in cold desert, Ladakh. 